\title{
Sağlık Bakım Çalışanlarına Yönelik Şiddet ve Etkileri
}

\section{Violence and Its Factors Towards Health Care Workers}

\author{
${ }^{1}$ Asif IQBAL, ${ }^{2}$ Naeem LIAQAT, ${ }^{3}$ Qurat-ul AIN, ${ }^{4}$ Fozia BASHIR, ${ }^{1}$ Wajeeh UR REHAM, \\ ${ }^{1}$ Imran HASHIM
}

\author{
${ }^{1}$ The Children's Hospital \& The Institute of Child Health, Lahore, Pakistan \\ ${ }^{2}$ Holy family Hospital Rawalpindi, Pakistan \\ ${ }^{3}$ DHQ Hospital Sheikhupura, Pakistan \\ ${ }^{4}$ Lahore General Hospital, Pakistan
}

\begin{abstract}
Asif Iqbal: https://orcid.org/0000-0002-6318-368X
Naeem Liaqat: https://orcid.org/0000-0003-1423-0440

Qurat-ul Ain: https://orcid.org/0000-0003-3997-8033

Fozia Bashir: https://orcid.org/0000-0002-0756-965X

Wajeeh Ur Reham: https://orcid.org/0000-0001-9966-180X

Imran Hashim: https://orcid.org/0000-0002-3741-9580
\end{abstract}

\begin{abstract}
ÖZ
Amaç: Dünya çapında işyeri şiddeti çok ciddi bir konudur. Diğer meslek gruplarıyla karşılaştırıldığında sağlık çalışanlarına yönelik şiddet veya saldırganlık riski daha yüksektir. Bu çalışmanın amacı, sağlık çalışanlarının şiddet prevalansını ve demografik faktörleri tespit etmektir.

Materyal ve Metot: $\mathrm{Bu}$ kesitsel çalışma Sheikhupura İlçesi Merkez Mahallesi Hastanesi'nde yapıldı. Gönüllï doktor ve hemşireler bu ankete dahil edildi. Veri toplama için İngilizce olarak tasarlanan bir anket kullanılmıștır. Yaş gibi nicel değişkenler ortalama \pm SD olarak sunuldu. Cinsiyet ve diğer demografik değişkenler gibi nitel değişkenler sıklık ve yüzde olarak sunuldu. Niteliksel kısım için temalar, NVIVO kullanılarak verilen cevaplara göre tanımlandı.
\end{abstract}

Bulgular: Bu çalışmaya katılan toplam katılımeı sayısı 199 idi. Ortalama yaş 30,69 $\pm 8,02$ y1l olarak bulundu. En fazla katılımcı $(\%$ 61,3) kadındı. En sık görülen tip sözel saldırganlık $(\% 75,8)$ idi. En s1k görülen şiddet yeri acil servisteydi $(\%$ 86,2) ve sabah vakti $(\% 50,9)$ idi. Erkek doktorlar sık sık kadınlara göre şiddet davranışları gözlemlemişler, fakat istatistiksel fark anlamlı bulunamamıştır. Şiddet, cerrahi ve tıp bölümünde de daha az deneyime sahip gençlerde olduğu gibi, daha da yaygın olarak gözlendi $(\mathrm{P}<0,05)$.

Sonuç: Bu çalıșmada genç sağlık çalıșanlarının daha fazla şiddete maruz kaldığı sonucuna varılmıştır. Toplumun bu davranışı, genç sağlık çalışanlarının ahlakını zedeleyebilir. $\mathrm{Bu}$ olayları önlemek için eğitim ve politikalara zaman ihtiyaç duyar.

Anahtar Kelimeler: Doktorlar, hemşireler, işyerinde şiddet, sağlık çalışanı

\section{ABSTRACT}

Objective Worldwide work place violence is a very serious issue. Compared with other occupational groups health care workers (HCW) are at a higher risk of violence or aggression. The objective of this study was to identify the prevalence of violence and the demographic factors among HCWs.

Materials and Methods: This cross sectional study was conducted at District Head Quarter Hospital, Sheikhupura. Willing doctors and nurses were included in this survey. An English self-designed questionnaire was used for data collection. The quantitative variables like age were presented mean $\pm \mathrm{SD}$. Qualitative variables like gender and other demographic variables were presented as frequency and percentages. For qualitative portion, themes were identifies according to the response using NVIVO.

Results: Total number of participants included were 199 into this study. Mean age was found as $30.69 \pm 8.02$ years. Maximum of participants $(61.3 \%)$ were female. Most common type was verbal aggression (75.8\%). Most common place of violence was emergency room $(86.2 \%)$ $\&$ morning time $(50.9 \%)$. Male doctors frequently observed violence behavior than female, however difference was not significant. Also violence was significantly more commonly observed in surgery \& medicine department also well as in youngster with less experience $(\mathrm{P}<0.05)$.

Conclusion: This study concluded that young health care workers face more violence. Behavior of this society may discourage the moral of young HCWs. Policies \& education to prevent these events is need of time.

Keywords:; Doctors, Health care worker, Nurses, Work place violence
Sorumlu Yazar / Corresponding Author:

Asif Iqbal

Senior registrar Paediatric surgery at The Children's Hospital \& The

Institute of Child Health, Lahore, Pakistan

Mobile: 00923314838518

E-mail: asiffsandhu@yahoo.com
Yayın Bilgisi / Article Info:

Gönderi Tarihi/ Received:16/10/2018

Kabul Tarihi/ Accepted: 11/10/2019

Online Yayın Tarihi/ Published: 30/06/2020

Atıf / Cited: Iqbal A, et al. Violence and Its Factors Towards Health Care Workers. Online Türk Sağllk Bilimleri Dergisi 2020;5(2):230239. doi: 10.26453 /otjhs.468863 


\section{INTRODUCTION}

The term "aggression" describes the behavior that is characterized by the intention to harm another person, while violence refers to the assault to a person with the intent to cause harm. ${ }^{1}$ Workplace violence is a phenomenon affecting every country, workplace and professional group to such extent that it can be characterized being endemic globally. ${ }^{2}$ So health care workers in particular are faced with the risk of being a victim of violence. ${ }^{3}$ According to international statistic data, nearly $4 \%$ of the total employee population has reported that they have suffered physical violence from people outside their workplace. ${ }^{4}$ More specifically, in health care areas, violence affects one in two healthcare professionals worldwide. However exact prevalence of violence and aggression towards Health Care Workers (HCW) are unknown as under reporting is common. ${ }^{5}$ A study conducted in 2014 reported that that junior male doctors (House officer) \& aged between 30-40 years old faced more events of violence. ${ }^{6}$ Another study from china published in 2017 showed that $57 \%$ doctors, $30 \%$ nurses, $5.4 \%$ technologist and $7.4 \%$ administration staff had been victim of workplace violence. They also found general medical \& surgical wards are most common places where these events occur more frequently than the other departments. ${ }^{3}$

This article was intended to highlight the reality of $\mathrm{HCW}$ facing violence while putting their efforts to provide care their own society \& to identify future research areas necessary to address the problem. No such study has been previously published from rural areas of our country where poverty and ratio of uneducated personal is much higher than developed nations. The objective of this study was to identify the prevalence of violence among $\mathrm{HCW}$ and to identify the demographic factors among HCWs.

\section{MATERIALS AND METHODS}

This cross sectional study was conducted at District Head Quarter Hospital, Sheikhupura; a district in Punjab. Duration of survey was 2 months from October to November 2017. After approval from ethical review board (Ethical board of hospital dated $7^{\text {th }}$ August, 2017) (Date: $7 / 8 / 2017$, decision no: IRB/27/2017), all the healthcare workers were asked to fill the proforma after verbal consent. As no separate consent form was included for participants, so inorder to maintain anonymity, they were told that filling the proforma mean that they are giving consent to be included in the study. An English selfdesigned questionnaire was used. The first part of questionnaire was about demographics details' including age, gen-der, years of experience in the rural area, educational level and their departments. Next question was, whether they had been exposed to any violent event in the past twelve months or not? Those who answer in the "yes" were requested to answer the further questions regarding that event. The respondents were also requested to explain the possible reasons of the violent act, they had encountered. The $3^{\text {rd }}$ part of questions was about reporting the event \& what was the reason behind being not reported anywhere. It was an open ended question \& all the respondents were free to count down the reasons. Data was analyzed by using SPSS version 20 . The quantitative variables like age were presented mean $\pm \mathrm{SD}$. Qualitative variables like gender and other demographic variables were presented as frequency and percentages. Some questions were stratified for demographic variables using chi-square test and taking $\mathrm{P}$ value $<0.05$ as significant. For qualitative portion, themes were identifies according to the response using NVIVO.

\section{RESULTS}

A total number of 199 participants were included in the study. Mean age was found as $30.69 \pm 8.02$ years, ranges; 19-56 years. Most of participants $(61.3 \%)$ were female. The demographic details are given in Table 1. Of 199, 153 participants (76.8\%) admitted that they have been exposed to violence in last 12 months.

We also asked for type of violence \& most common type was verbal aggression experienced by 116 respondents (75.8\%). Most common place of violence was Emergency (ER) reported by 132 respondents (86.2\%) \& occurring at morning time in $50.9 \%$ of cases. Most of the participants mentioned that violence was done by patient's relatives. All details are given in Table 2.

So, the occurrence of violence was stratified for demographic variables. Although violence behavior was more frequently observed by male doctors than female, however difference was not significant $(\mathrm{p}=$ 0.120 ). Also violence was significantly more commonly observed in surgery \& medicine department and in youngster with less experience ( $\mathrm{P}$ $<0.05$ ), details are given in Table 3 . 
We found that the patient's relatives are most common source of violence. In this survey the thoughts of the participants is that lack of security which was responsible in $58.8 \%$ cases., followed by overcrowding $41.1 \%$, negative media impact, $37.9 \%$ $\&$ shortage of staff 20.2, details are shown in Figure 1.

Our final question to the respondents was "whether you reported the incident, and if no then why?" We found that 24 respondents told the cause of not reporting the incident. The most common theme was found to be the 'lack of interest of administration to take any action' by $37.5 \%$ of respondents $(n=9)$, followed by 'due to busy schedule, no time for reporting' by $21.9 \%$ of respondents. All the themes are summarized in Table 4.

\section{DISCUSSION AND CONCLUSION}

Worldwide work place violence (WPV) is a very serious issue with an increasing trend. ${ }^{7}$ WPV can occur in any organization, against any person and at anytime. However, compared with other occupational groups $\mathrm{HCW}$ are at a higher risk of violence or aggression. ${ }^{4}$ According to literature the prevalence of violence \& aggression towards $\mathrm{HCW}$ ranges between 0.04 to $91 \% .{ }^{8}$ It affects not only the emotional or mental well being of the victims but also negatively affect quality of work performance. ${ }^{9}$ In our study, $199 \mathrm{HCW}$ were offered to fill the questionnaire \& 153 reported that they faced WPV in last 12 months, which is $76.8 \%$. An Egyptian author reported that $75 \% \mathrm{HCW}$ faced violence \& aggression; HCW from US \& Nigeria reportedly face WPV $75 \%$ \& $69 \%$ respectively. ${ }^{10}$ The mean age of our participants ware $30.69 \pm 8.02$ years. Farhan et al conducted a study in similar age group with mean age being $31 \pm 7.68$ years. ${ }^{11}$ Age group in present study is also comparable with Chen et al, who found it $27.68 \pm 3.42$ years. ${ }^{12}$

About $75 \%$ of respondents who had an experience of violence, observed verbal aggression. Similar percentage of violence type i.e. verbal threats to physician reported by James P. ${ }^{13}$ Another study from Hon Kong showed that verbal abuse is the most common type of violence against doctors (38.3\%) \& nurses (56.0). ${ }^{14}$ Participants having less than five year experience were the most common victims (71\%) of violence \& aggression while only $6 \%$ senior members with experience of 20 years had been victims. A study from 2013 reported that resident nurses \& doctors are the most common victims of violence. ${ }^{15}$ Our results were comparable with Rubeena et al, who reported that $1 / 2$ of the responder facing verbal abuses were less than thirty years of age while those older than this, never faced violence. $^{16}$

The study revealed that emergency or trauma center was the most common site of violent events \& results were comparable with national \& international data. A case study was conducted in Australia which found that nurses of emergency department experienced more episodes of violent events than those working in other departments. ${ }^{17}$ According to present study; half participants faced violent events in morning shift. An Indian study disagreed with findings of this study and reported that violent events are common after OPD hours (9am -1pm). ${ }^{6}$ However Nazish et al. reported that more events were seen during morning hours. ${ }^{18}$ Another study from United Stated reported that nurses face violent events more commonly in morning hours (52.1\%) compared to evening (13.0), night times $(25.7 \%)$ and rotating hours $(9.2 \%) .{ }^{19}$

This study found that the patient's relatives were the most common source of violence. Similar finding were noted by Imran $\mathrm{N}$ et al. ${ }^{18}$ Another study reported that in $90.1 \%$ of events, attendants of the patients were responsible for violence against health security workers. ${ }^{20}$ Participants in this survey thought that lack of security was responsible in $58.8 \%$ case, followed by overcrowding $41.1 \%$, negative media impact, $37.9 \%$ \& shortage of staff $20.2 \%$. According to Algwaiz,et al, shortage of staff is main source of violence. ${ }^{21}$

As violence is vast terminology depends upon many factors and stimulations, so assessing such events in quantitative study cannot uncompress the whole spectrum of events. This is the main limitation of the study and a detail qualitative study must be conducted to understand the dynamics of events. However conducting such studies at a secondary care hospital in our county definitely help to understand the magnitude of problems as violence was much prevalent.

In conclusion, this study concludes that young health care workers face more violence during working hours. This behavior of society may discourage the moral of young HCWs. At Government level, policies \& education of masses to prevent these events is need of time. Also the laws need to be implemented to prevent the occurrence of such events. 
Ethics Committee Approval: Our study was approved by the Ethical committee of District Headquarters Hospital, Sheikhupura (Date: 7/8/2017, decision no: IRB/27/2017).

Conflict of Interest: No conflict of interest was declared by the authors.

Author Contributions: Concept - IA; Supervision LN, AQ, BF; Materials - RW, HI; Data Collection and/or Processing - IA, LN; Analysis and/ or Interpretation -AQ, BF; Writing - LN, RW.

Peer-review: Externally peer-reviewed.

Acknowledgement: The authors thank to Dr. Khawar Rafiq, Head of Surgery, District Headquarters Hospital, Sheikhupura, for his immense support and guidance.

\section{REFERENCES}

1. Zimmerman GM, Kushner M. Examining the Contemporaneous, Short-Term, and LongTerm Effects of Secondary Exposure to Violence on Adolescent Substance Use. J Youth Adolesc. 2017;46(9):1933-1952.

2. Kumar NS, Munta K, Kumar JR, Rao SM, Dnyaneshwar M, Harde Y.A survey on workplace violence experienced by critical care physicians. Indian J Crit Care Med. 2019 Jul;23(7):295-301.

3. Sun $\mathrm{P}$, Zhang $\mathrm{X}$, Sun $\mathrm{Y}$, et al. Workplace violence against health care workers in North Chinese hospitals: a cross-sectional survey. International Journal of Environmental Research and Public Health. 2017;14(1):96. doi: 10.3390/ijerph14010096.

4. Stathopoulou H. Violence and aggression towards health care professionals. Health Science Journal. 2007;1(2):1-7.

5. d'Ettorre G, Pellicani V. Workplace violence toward mental healthcare workers employed in psychiatric wards. Safety and Health at Work. 2017;8(4):337-342.

6. Kumar M, Verma M, Das T, Pardeshi G, Kishore J, Padmanandan A. A study of workplace violence experienced by doctors and associated risk factors in a tertiary care hospital of South Delhi, India. J Clin Diagn Res. 2016;10(11):LC06-LC10.

7. Ferri P, Silvestri M, Artoni C, Di Lorenzo R. Workplace violence in different settings and among various health professionals in an Italian general hospital: a cross-sectional study. Psychology Research and Behavior Management. 2016;9:263-275.
8. Nijman H, Palmstierna T, Almvik R, Stolker J. Fifteen years of research with the Staff Observation Aggression Scale: a review. Acta psychiatrica Scandinavica. 2005;111(1):12-21.

9. Chopra P. Mental health and the workplace: issues for developing countries. Int $\mathrm{J}$ Ment Health Syst 2009;3(1):4. Doi:10.1186/17524458-3-4.

10. Abdellah RF, Salama KM. Prevalence and risk factors of workplace violence against health care workers in emergency department in Ismailia, Egypt. Pan African Medical Journal. 2017;26(1):1-8.

11. Ahmed F, Memon MK, Memon S. Violence against doctors, a serious concern for healthcare organizations to ponder about. Annals of Medicine and Surgery. 2018;25:3-5. doi: 10.1016/j.amsu.2017.11.003.

12. Chen W-C, Sun Y-H, Lan T-H, Chiu H-J. Incidence and risk factors of workplace violence on nursing staffs caring for chronic psychiatric patients in Taiwan. International Journal of Environmental Research and Public Health. 2009;6(11):2812-2821.

13. Phillips JP. Workplace violence against health care workers in the United States. New England Journal of Medicine. 2016;374 (17):1661-1669.

14. Cheung T, Lee PH, Yip PS. Workplace violence toward physicians and nurses: prevalence and correlates in Macau. International Journal of Environmental Research and Public Health. 2017;14(8):879. doi: 10.3390/ijerph14080879.

15. Koukia E, Mangoulia P, Gonis N, Katostaras T. Violence against health care staff by patient's visitor in general hospital in Greece: Possible causes and economic crisis. Open J Nurs. 2013;3(08):21-27.

16. Zakar R, Zakar MZ, Krämer A. Voices of strength and struggle: Women's coping strategies against spousal violence in Pakistan. Journal of interpersonal violence. 2012;27 (16):3268-3298.

17. Mayhew C, Chappell D. Workplace violence in the health sector-a case study in Australia. Safety. 2003;19(6):1-43.

18. Imran N, Pervez MH, Farooq R, Asghar AR. Aggression and violence towards medical doctors and nurses in a public health care facility in Lahore, Pakistan: A preliminary 
investigation. Khyber Med Uni Med J. 2013;5 (4):179-184.

19. Gacki-Smith J, Juarez AM, Boyett L, Homeyer C, Robinson L, MacLean SL. Violence against nurses working in US emergency departments. Journal of Nursing Administration. 2009;39 (7/8):340-349.

20. Shafran-Tikva S, Chinitz D, Stern Z, FederBubis P. Violence against physicians and nurses in a hospital: How does it happen? A mixed-methods study. Isr J Health Policy Res. 2017;6(1):59. doi: 10.1186/s13584-017-0183y.

21. Algwaiz WM, Alghanim SA. Violence exposure among health care professionals in Saudi public hospitals. A preliminary investigation. Saudi Medical Journal. 2012;33 (1):76-82. 
Table 1. Demographic details of participants.

\begin{tabular}{|l|c|c|}
\hline \multicolumn{2}{|c|}{ Age (Mean \pm SD) 30.34 \pm 1.12 } \\
\hline \multicolumn{2}{|c|}{ Gender } \\
\hline Pale & 77 & Percentage (\%) \\
\hline Female & 122 & 38.7 \\
\hline \multicolumn{2}{|c|}{ Position } \\
\hline Doctor & 138 & 61.3 \\
Nursing Staff & 47 & 23.6 \\
Paramedical Staff & 15 & 7.0 \\
\hline \multicolumn{2}{|c|}{ Experience (in years) } \\
\hline < y years & 143 & 71.8 \\
5- 10 years & 23 & 11.5 \\
11-20 years & 21 & 10.5 \\
>2o yeas & 12 & 6.0 \\
\hline \multicolumn{2}{|c|}{ Department } \\
\hline Anesthesia & 3 & 1.5 \\
Surgery \& allied & 65 & 32.7 \\
Gynaecolgy \& Obstetrics & 11 & 5.5 \\
Pediatric Medicine & 11 & 5.5 \\
Medicine \& allied & 94 & 47.2 \\
Emergency Department & 15 & 7.5 \\
\hline
\end{tabular}


Table 2. Details of participant's response against violence.

\begin{tabular}{|l|c|c|}
\hline Type of Violence & $\mathbf{n = 1 5 3}$ & Percentage (\%) \\
\hline Physical aggression & 14 & 9.1 \\
Verbal aggression & 116 & 75.8 \\
Threats & 14 & 9.1 \\
Harassment & 5 & 3.2 \\
Verbal \& physical & 4 & 2.6 \\
\hline \multicolumn{2}{|c|}{ PLACE OF VIOLENCE } \\
\hline Emergency 132 & 86.2 \\
Ward & 13 & 8.4 \\
O.P.D & 8 & 5.2 \\
\hline \multicolumn{3}{|c|}{ TIME OF VIOLENCE } \\
\hline Morning & 78 & 50.9 \\
Evening & 61 & 39.8 \\
Night & 14 & 8.4 \\
\hline \multicolumn{2}{|c|}{ SOURCE OF VIOLENCE } \\
\hline Patient's relatives & 137 & 89.5 \\
Co-workers & 7 \\
Patients & 9.5 \\
\hline
\end{tabular}


Table 3. Violence for demographic variables.

\begin{tabular}{|c|c|c|c|}
\hline \multirow[t]{2}{*}{ Variables } & \multicolumn{2}{|c|}{ Violence } & \multirow[t]{2}{*}{ p-Value } \\
\hline & Yes & No & \\
\hline \multicolumn{4}{|l|}{ Gender } \\
\hline Male & 64 & 13 & 0.120 \\
\hline Female & 89 & 33 & \\
\hline \multicolumn{4}{|c|}{ Position } \\
\hline Doctor & 112 & 26 & 0.102 \\
\hline Nursing Staff & 33 & 14 & \\
\hline Paramedical Staff & 8 & 6 & \\
\hline \multicolumn{4}{|c|}{ Department } \\
\hline Anesthesia & 0 & 3 & \\
\hline Surgery allied & 46 & 19 & $0.002 *$ \\
\hline Gynae \& Obs & 8 & 3 & \\
\hline Paeds & 7 & 4 & \\
\hline Medicine \& allied & 77 & 17 & \\
\hline ER & 15 & 0 & \\
\hline \multicolumn{4}{|c|}{ Experience } \\
\hline$<5$ years & 112 & 31 & \\
\hline $5-10$ years & 18 & 5 & $0.002 *$ \\
\hline $11-20$ years & 19 & 2 & \\
\hline$>20$ yeas & 4 & 8 & \\
\hline
\end{tabular}

* It is statistically significant $(p<0.05)$. 
Table 4. Reasons for not reporting the incident.

\begin{tabular}{|l|c|}
\hline Reason & N (\%) \\
\hline Lack of interest of administration to take any action & $9(37.5 \%)$ \\
\hline Due to busy schedule, no time for reporting & $7(29.16 \%)$ \\
\hline I don't have any interest in it & $2(8.33 \%)$ \\
\hline Violence is everywhere and a common problem & $4(16.66 \%)$ \\
\hline Nobody takes it serious & $2(8.33 \%)$ \\
\hline
\end{tabular}




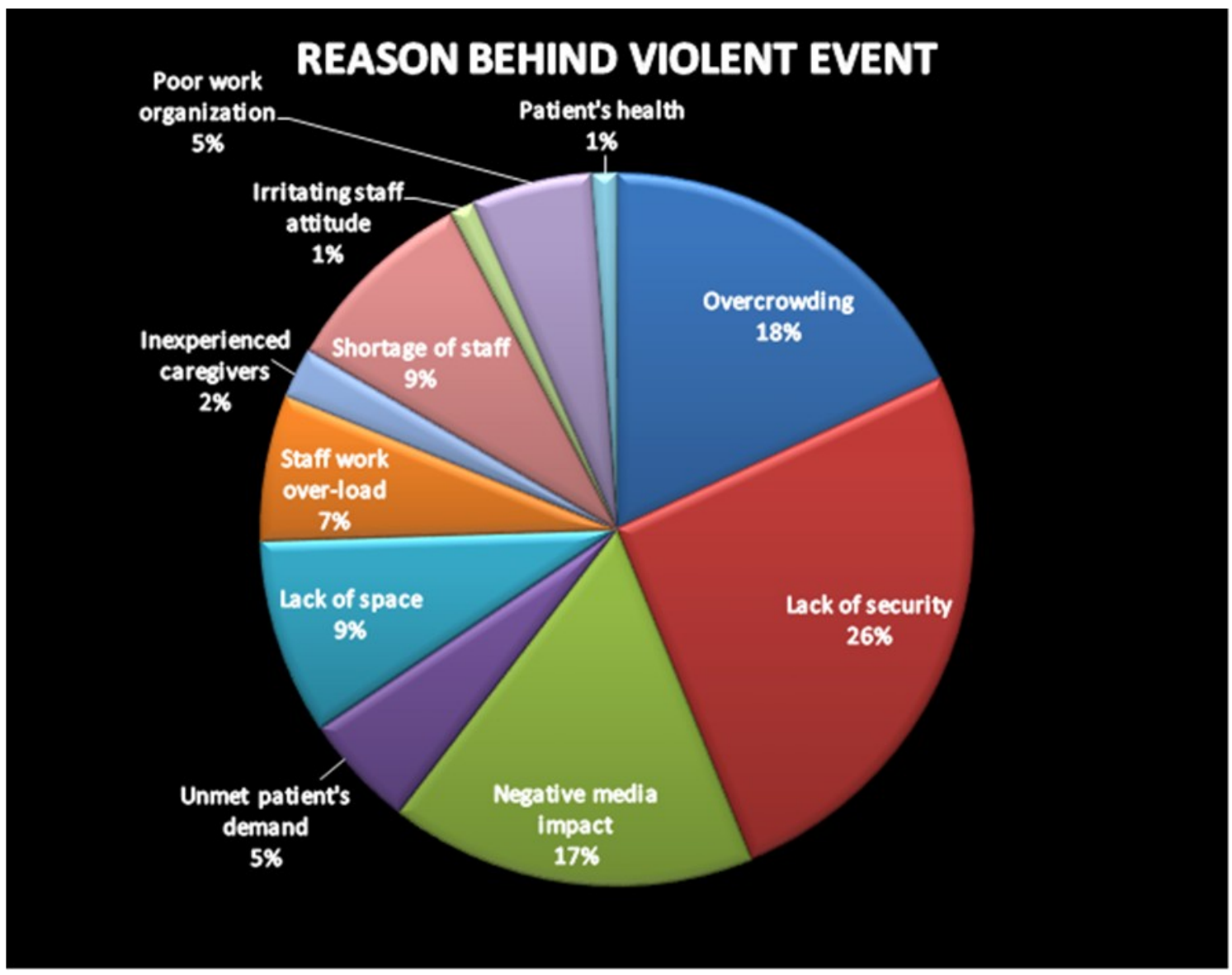

Figure 1. Reasons behind violent event. 